The University of Maine

DigitalCommons@UMaine

Publications

Senator George J. Mitchell Center for Sustainability

Solutions

$7-2014$

\title{
Creating Successful Vernal Pools: A Literature Review and Advice for Practitioners
}

\author{
Aram J K Calhoun \\ University of Maine, Calhoun@maine.edu \\ J.Arrigoni \\ State University of New York College of Environmental Science and \\ Malcolm L. Hunter Jr. \\ University of Maine, mhunter@maine.edu \\ C. Richter \\ Eastern Kentucky University
}

Follow this and additional works at: https://digitalcommons.library.umaine.edu/ mitchellcenter_pubs

\section{Repository Citation}

Calhoun, Aram J K; Arrigoni, J.; Hunter Jr., Malcolm L.; and Richter, C., "Creating Successful Vernal Pools: A Literature Review and Advice for Practitioners" (2014). Publications. 16.

https://digitalcommons.library.umaine.edu/mitchellcenter_pubs/16

This Article is brought to you for free and open access by DigitalCommons@UMaine. It has been accepted for inclusion in Publications by an authorized administrator of DigitalCommons@UMaine. For more information, please contact um.library.technical.services@maine.edu. 


\section{Creating Successful Vernal Pools: A Literature Review and Advice for Practitioners}

A. J. K. Calhoun, J. Arrigoni, R. P. Brooks, M. L. Hunter, S. C. Richter

A. J. K. Calhoun, M. L. Hunter

Department of Wildlife, Fisheries, and Conservation Biology,

University of Maine, Orono, ME 04469, USA e mail: calhoun@maine.edu

J. Arrigoni

Department of Environmental and Forest Biology, State University of New York College of Environmental Science and Forestry, Syracuse, NY 13210, USA

P. Brooks

Riparia, Department of Geography, Pennsylvania State University, University Park, PA 16802, USA

C. Richter

Department of Biological Sciences and Division of Natural Areas, Eastern Kentucky University, Richmond, KY 40475, USA 
Abstract

Vernal pools provide critical breeding habitat for amphibians adapted to temporary waters, but they seldom receive the same level of protection as permanent wetlands. In response to continued degradation and loss of pools, managers often attempt to mitigate losses through pool creation or restoration. However, mitigation efforts often fail to provide suitable aquatic habitat for vernal pool amphibians. We review the literature on pool creation in northeastern and central North America, highlighting how and why constructed pools often fail to support amphibian related objectives. We recommend that practitioners consider the complex ecology of pool ecosystems and the historical and current distribution of pools and other wetlands in their local context before designing pool mitigation projects. Using vernal pool creation as a mitigation option should be a last resort (i.e., when elimination of natural pools is unavoidable). Monitoring should be target specific and conducted for at least 5 years. Topographic, geologic, and other local factors affecting pool hydrology and ecology vary regionally; pool creation remains an imperfect science that will only advance by documenting failures and successes. We recommend an adaptive management approach to vernal pool creation in which the effectiveness of techniques is evaluated and refined based on research.

Keywords: Ambystomatid salamanders, Ephemeral wetlands, Pool breeding amphibians, Restoration, Seasonal depressions, Vernal pool creation, Wetland creation, Wood frogs 
Introduction

Vernal pools in the central to northeastern regions of North America are seasonal wetlands in forested landscapes, free of permanent fish populations. As their name suggests, they typically are most fully inundated in the spring, and may also be referred to as temporary ponds, ephemeral wetlands, or various combinations thereof. Vernal pools provide the core breeding habitat for wood frogs (Lithobates sylvaticus), mole salamanders (Ambystoma spp.), and invertebrates (notably fairy shrimp [Anostraca]) adapted to life in temporary waters, but they are often inadequately protected because of their small size and ephemeral nature. When pools are lost or severely degraded, mitigation efforts often rely on pool creation or restoration to replace breeding habitat for pool associated amphibians. It is essential to distinguish creation of vernal pools from restoration because the context is often very different. Creation usually occurs either as a compensatory mitigation requirement accompanying the removal of an intact, naturally occurring vernal pool, or as part of a proactive program to augment or diversify habitat by building new pools. Vernal pool restoration projects, however, attempt to return a pool from an altered or degraded condition to a preexisting condition (National Research Council 1992; Brooks and Gebo 2013). This paper focuses on creation of vernal pools, and while creation and restoration approaches can vary dramatically, much of the relevant literature is also applicable to restoration.

While replacing a hectare of natural wetland with a hectare of created wetland may result in no net loss of wetland area, there is likely to be a net loss of ecological functioning (Hoeltje and Cole 2007; Dahl 2011; Moreno Mateos et al. 2012). In particular, early reviews by Kusler and Kentula (1990) and Kentula et al. (1992) demonstrated that wetlands created for compensatory mitigation often failed to reliably replace natural wetland functions. This shortcoming is addressed in more recent guidance from the U.S. Environmental Protection Agency (2008) regarding the national "Mitigation Rule." Under most circumstances, U.S. federal and some state wetland regulations require that both area and functional impacts to vernal pools be mitigated. However, recent legal cases have raised the issue about whether hydrologically isolated wetlands should receive the same degree 
of protection as those with surface connections to navigable waters (Mahaney and Klemens 2008). This situation threatens vernal pools in particular (e.g., Leibowitz 2003) and highlights the need for clear, effective mitigation strategies.

By definition, wetland restoration seeks to reestablish a wetland's physicochemical, hydrological, and ecological functions (National Research Council 2001), and presumably vernal pool creation also seeks to establish new pools with functions similar to those of natural pools. However, vernal pools are among the most difficult wetland ecosystems to create or restore primarily because of their hydrological properties: particularly, the seasonal water regime that is their defining feature. Furthermore, vernal pool creation or restoration must be coupled with adjacent high quality post breeding habitat for the biphasic amphibian species that depend on these pools for breeding, but spend most of their lives in adjacent habitats (Lichko and Calhoun 2003; Semlitsch 2008; Simon et al. 2009).

For practitioners seeking guidance on vernal pool mitigation strategies, published information can be confusing and conflicting. Some manuals for vernal pool creation suggest creating pools is easy (Biebighauser $2003,2011)$, yet peer reviewed papers to date report generally poor or ambiguous results in terms of providing breeding habitat to vernal pool associated amphibians (Lichko and Calhoun 2003; Petranka et al. 2003; Vasconcelos and Calhoun 2004, 2006; Petranka et al. 2007; Korfel et al. 2009; Gamble and Mitsch 2009; Denton and Richter 2013). In this paper, we review the current literature on pool creation in central to northeastern North America (referred to below as the region) as pool creation is common in this area yet the relevant literature has not been synthesized. However, analogous research on the creation of small, often temporary, pools has been undertaken in other parts of the world, e.g., Australia (Brainwood and Burgin 2009), Brazil (da Silva et al. 2011), California (Black and Zedler 1996), Spain (Ruhi et al. 2012), and the United Kingdom (Williams et al. 2008). The purpose of this paper is to fill this gap by:

(1) providing a summary of the major findings in the current vernal pool creation literature in our region with a 
focus on key indicator amphibians (wood frogs and ambystomatid salamanders);

(2) defining an ecologically appropriate endpoint for successful creation;

(3) providing general recommendations to practitioners gleaned from the literature;

(However, it is not the goal of this review to provide a "how to" manual for vernal pool creation); and (4) identifying research gaps that should be a focus of pool creation studies.

Although we have focused on one region in North America, we believe our recommendations for approaches to management and future research are relevant, at least conceptually, to other ephemeral wetlands around the world.

Vernal pools and key pool breeding amphibian species

Vernal pools provide critical breeding and nursery habitat, where amphibian eggs and larvae develop and emerge as metamorphs to adjacent forests, for wood frogs and species of mole salamanders. Pools may provide additional breeding sites for other species, including (but not limited to) four toed salamanders (Hemidactylium scutatum), American toads (Anaxyrus americanus), eastern spadefoots (Scaphiopus holbrookii), upland chorus frogs (Pseudacris feriarum), and fairy shrimp (Anostraca) (Calhoun and deMaynadier 2008). In addition, adult amphibians may use pools as stepping stones while moving to summer and winter refugia (Semlitsch 1998; Baldwin et al. 2006a). Pools in the region are typically located in forested settings where shaded, cool conditions with abundant leaf litter and coarse woody material support detrital based food webs in the pools (Palik et al. 2006; Magnusson and Williams 2006). Wood frogs, mole salamanders, and certain other species of amphibians are well adapted to these relatively nutrient poor systems where they have limited competition and reduced depredation from fish, other amphibians, and invertebrates associated with more permanent waters and more open canopy pools (deMaynadier and Houlahan 2008; Denton and Richter 2013). 
How do we measure success?

A mitigation project should have defined goals, or endpoints of success. From our perspective, successful pool creation is demonstrated by reproduction and metamorphosis by key indicator species such as wood frogs and ambystomatid salamanders for the long term (i.e., not just the 5 year monitoring period). In practice, regulators and managers often use a lower standard of "success," e.g., simply the presence of any amphibian species or the presence of a given target species within the first 2 years after creation (Lichko and Calhoun 2003); however, these metrics may be misleading. Created pools may be colonized by dispersing individuals from other breeding pools, or, in the case of onsite mitigation, by returning members of the original pool breeding population, but their presence is not indicative of successful breeding (Vasconcelos and Calhoun 2006).

Furthermore, monitoring protocols generally require as little as 2 years of monitoring post creation (Lichko and Calhoun 2003). Our review of the literature, however, underscores the importance of monitoring periods for a minimum of 5 years to incorporate demographic and environmental variability such as the interaction between climate (temperature and precipitation variability) and hydro-period. For example, it may take more than 5 years for green frog (Lithobates clamitans) or bullfrogs (L. catesbeianus), voracious predators of wood frog and salamander egg masses and larvae, to establish in semi-permanent or permanent pools at densities that generate a detrimental effect on the classic pool breeders using those same pools (Vasconcelos and Calhoun 2004; Denton and Richter 2013).

Below we review key factors that affect pool success from the perspective of key pool breeding amphibians. We look at both pool specific factors and larger scale issues associated with pool landscape setting. We address pool specific concerns and landscape scale issues separately for simplicity while recognizing that there are many interactions between the two. 
Hydrology

The hydrology of any given pool will be dictated by hydro-geomorphic setting (i.e., the landscape position of a pool in the watershed that dictates the major inputs and outputs of water to the system), as well as more proximate factors such as canopy cover (i.e., evapotranspiration), pool surface area, volume, depth, and connection to groundwater (Cole and Brooks 2000). Periodic drying (usually in summer, occasionally in autumn and winter) excludes resident populations of predatory fish, reduces the diversity and abundance of invertebrate predators, and limits competition and depredation from other amphibian species (Drayer 2012; Denton and Richter 2013; Julian et al. 2013). Additionally, amphibian diseases may be more likely to persist in permanent wetlands than in those that dry (Gray et al. 2009; Richter et al. 2013a). For these reasons, hydro-period (i.e., the timing and duration of inundation), is particularly critical to vernal pool ecosystem functions (Zedler 2000); even variations in vernal pool filling and drying on the order of 2 to 3 weeks can alter pool breeding amphibian community composition and the success of any given species (Paton and Crouch 2002; Babbitt et al. 2003; Baldwin et al. 2006a; Good 2006; Seigel et al. 2006; Timm et al. 2007). For example, wood frog and spotted salamanders deposit eggs early in the spring, but wood frog embryos and larvae develop more rapidly than spotted salamanders, necessitating a substantially longer hydro-period to support successful reproduction for spotted salamanders (Fig. 1). In contrast, marbled salamanders (Ambystoma opacum) deposit eggs in dry basins in autumn. Eggs hatch after vernal pools recharge, and overwintered larvae metamorphose on a schedule similar to wood frogs.

A number of studies report significantly longer hydro-periods for created pools versus natural pools as well as differences in water chemistry owing to miscalculation of water table depths or compacted soils impeding drainage (diMauro and Hunter 2002; Gamble and Mitsch 2009; Korfel et al. 2009; Drayer 2012; Denton 
and Richter 2013). Longer hydro-periods, particularly semi-permanent to permanent, may mean increased numbers of amphibian species and invertebrates that prey upon target vernal pool breeders. Notably, green frog and bullfrog larvae, which take 2 to 3 years to develop, and eastern newt (Notophthalmus viridescens) adults are efficient predators of wood frog and ambystomatid egg masses and larvae, and may be abundant in created semi-permanent to permanent ponds (Kross 2014). These species are also potential reservoirs of disease (Daszak et al. 2004; Gahl et al. 2012). Denton and Richter (2013) reported that in Kentucky wood frogs and marbled salamanders were almost exclusively found in natural, ephemeral wetlands, whereas large frogs (e. g., green frogs and bullfrogs) and eastern newts were only found breeding in permanent, constructed wetlands. In this system, newts and ranid larvae consumed all wood frog eggs (100-190 clutches) and many ambystomatid eggs in four created pools over a 4 week period (Richter and Drayer, unpubl. data). In Maine, green frogs consumed all the wood frog egg masses (over 100) in two created pools in less than 1 week (Vasconcelos and Calhoun 2004). In short, failure of created pools to support viable populations of specialized pool breeders is often directly attributable to improper hydrological regime (Porej et al. 2004; Vasconcelos and Calhoun 2006; Gamble and Mitsch 2009; Drayer 2012; Denton and Richter 2013; Kross 2014).

Hydro-geomorphic setting

Vernal pools may develop in a variety of hydro-geomorphic settings including riparian areas, surface water depressions (often in the upper reaches of a watershed), and as groundwater depressions in low lying areas (either embedded in larger wetlands or as discrete depressions). Each of these settings is characterized by different hydro-periods (ranging from ephemeral to semi-permanent vernal pools) and major water inputs (e.g., precipitation, groundwater inflow, subsurface flow, and runoff) that may influence water temperature, pool substrate, and water chemistry (Whigham and Jordan 2003; Sacerdote and King 2009; Gebo and Brooks 2012). For example, pools that receive inputs from groundwater as well as from surface runoff tend to have mucky soils and water chemistry that is less variable than pools supported primarily by surface water. Water chemistry and 
temperature will affect rates of embryo and larval development in pools (Newman 1998; Karraker et al. 2008; Battaglin et al. 2009). Local populations of amphibians may be particularly adapted to these subtle differences in pool setting (Rice and Emery 2003; Brady 2012). However, there is no published information on how to create pools in these different landscape settings to ensure replication of the abiotic environment.

Vegetation

Within pool vegetation structure. In our region, the composition and structure of pool vegetation varies greatly, and only a few plant species are true vernal pool obligates (e.g., Scirpus ancistrochaetus [northeastern bulrush] and Hottonia inflata [feather-foil]; Cutko and Rawinski 2008; Drayer 2012; Denton and Richter 2013; Pennsylvania Natural Heritage Program 2013). Although vegetation in pools may be important for providing shade, refuge, and potential egg attachment sites (Porej and Hetherington 2005; Vasconcelos and Calhoun 2006; Skidds et al. 2007; King 2012), many pools may be largely devoid of vascular plants. In these cases, fine and coarse woody material deposited in pools from adjacent trees and shrubs may serve as egg attachment sites and refugia from predation.

Potential for invasive species. The potential for colonization by weedy plants in created pools is high, and pools can become dominated by monocultures of cattail (Typha spp.), common reed (Phragmites spp. ), purple loosestrife ( Lythrum salicaria ), or duckweed (Lemna spp.) in disturbed sites, especially in pools located in more open settings. These plants can eventually fill or dry out a vernal pool, dramatically changing the hydro-period and altering pool chemistry and temperature (Vasconcelos and Calhoun 2004; Cutko and Rawinski 2008).

Pool canopy cover. Canopy cover adjacent to pools affects pool temperature and supporting detrital food webs through inputs of leaf litter, which impacts developmental rates and species interactions (reviewed in deMaynadier and Hunter 1995; Schiesari 2006; deMaynadier and Houlahan 2008). Canopy removal directly over 
and around vernal pools may alter amphibian community composition as increased light, temperature, and primary productivity may attract a broader array of amphibian and invertebrate species that either compete or prey on pool breeding specialists (Brooks et al. 1998; Calhoun and deMaynadier 2002; Skelly et al. 2002; Denton and Richter 2013). Thus, reduction in canopy cover may preferentially support species typically found in opencanopy wetlands to the detriment of vernal pool specialists. For example, Schiesari (2006) found that northern leopard frogs (Lithobates pipiens) outperformed wood frogs in open canopy, but not closed canopy conditions. Additionally, pools may become dominated by algae and duckweed, ultimately reducing oxygen levels (e.g., by limiting light infiltration and reducing algal photosynthesis) and limiting their suitability for target pool breeders (Vasconcelos, unpublished data).

Slope

Most natural vernal pools have shallow littoral zones available with gradual slopes to the center, which has been linked to greater species richness compared to constructed wetlands (Porej and Hetherington 2005; Drayer 2012). In the ridgetop wetland ecosystem of Kentucky, Drayer (2012) found natural wetlands to have significantly lower slope (measured as depth at $1 \mathrm{~m}$ from shore; mean $\pm 1 \mathrm{SE}=9.1 \pm 0.8 \mathrm{~cm}$ ) than constructed wetlands $(15.4 \pm 1.6 \mathrm{~cm})$. Created pools that do not mimic the slope of natural pools may be less suitable for amphibian recruitment (Porej and Hetherington 2005; Croshaw and Scott 2006). Steep, abrupt slopes may cause access problems for salamanders and may limit the growth of vegetation (Simon et al. 2009; Shulse et al. 2012) or the rate of melting ice cover in northern climates. Additionally, shallow areas can be important for predator avoidance (Porej and Hetherington 2005), thermoregulation of amphibians for growth (Wellborn et al. 1996) and to decrease the occurrence of diseases (Raffel et al. 2010). Optimal slopes vary from pool to pool depending on typical levels of winter and fall rains (Croshaw and Scott 2006). Marbled salamanders are particularly sensitive to changes in pool slope because their selection of nesting sites depends on the interplay of pool bathymetry and water levels determined by winter and fall rains (Croshaw and Scott 2006). 
Soils

Soil development is highly dependent upon hydro-period (i.e., longer hydro-periods result in saturated conditions that can create mucky, organic surface layers) and parent materials (e.g., highly permeable sandy outwash materials versus compact, restrictive tills; Tiner and Veneman 1989). If creation efforts properly mimic the necessary hydrology and pools are placed in appropriate hydro-geomorphic settings, soil development in created sites should be similar to that of natural pools (see Biebighauser 2003). If soils from the original wetland are excavated and used in the created wetland, this should enhance the likelihood of colonization by native species (i.e., by plant seeds and resting stages of invertebrates or dormant cysts or eggs; Stauffer and Brooks 1997; Colburn et al. 2008).

Soil compaction in created pools may influence hydro-period (Whittecar and Daniels 1999; Gamble and Mitsch 2009). If the soils have sufficient clay, then they can be readily compacted to hold water (Biebighauser 2003, 2011). However, there is always a risk that they will hold water too long (Korfel et al. 2009). For example in Kentucky, constructed wetlands with the same hydro-geomorphic parameters as natural wetlands and maximum depths less than $30 \mathrm{~cm}$ were permanently inundated, presumably because of soil compaction (Drayer 2012; Denton and Richter 2013).

Landscape setting and pool context affect success of creation projects

Because of the complex life histories of pool breeding specialists, conservation efforts must support critical population dynamics including migration from winter hibernacula to breeding pools, migration from breeding pools to summer habitat, migration from summer refugia to hibernacula, and juvenile dispersal (leaving the natal pool to breed in new pools). Not all pool breeding amphibians have the same post breeding habitat 
needs (see Baldwin et al. 2006a; Semlitsch et al. 2008; Rittenhouse and Semlitsch 2007). For example, wood frogs in the northeastern U.S. often require three distinct habitat elements including the breeding pool, summer refugia of forested wetlands or hillside seeps, and well drained upland forests for hibernation (Baldwin et al. 2006b, Groff, unpublished data). In contrast, salamanders may require fewer habitat elements, but may be more sensitive to habitat disturbance closer to the pool and to disruption of migration routes (McDonough Haughley and Paton 2007).

The literature emphasizes the importance of the forest matrix linking pools as post breeding habitat and as migratory and dispersal corridors (see Compton et al. 2007; Harper et al. 2008; Greenwald et al. 2009; Baldwin and deMaynadier 2009; Denton and Richter 2013; Peterman et al. 2013). Abundant coarse woody material and leaf litter on the forest floor and at least $50 \%$ canopy cover have been suggested as key components of suitable forest habitat (Gibbs 1998; Patrick et al. 2006; deMaynadier and Houlahan 2008). Disturbance thresholds for each species of pool breeding amphibian have not been widely investigated, but a number of case studies (Gibbs 1998; Homan et al. 2004; Windmiller et al. 2008; Windmiller and Calhoun 2008) and extinction models (Harper et al. 2008) suggest that current regulatory zones around pools in states with specific vernal pool legislation are inadequate for conserving pool breeding amphibian populations. Altering as little as $25 \%$ of post breeding habitat adjacent to pools led to local extinctions in two Massachusetts vernal pools (Windmiller et al. 2008).

In addition to affecting upland habitat quality for amphibians, upland vegetation characteristics may influence pool characteristics at large spatial scales. Skelly et al. (1999) suggested that forest recovery following agricultural abandonment increased evapotranspiration rates, leading to decreased hydro-periods. Presumably, any changes to vegetation within the catchment area of a pool, such as those caused by succession or timber harvest, have the potential to affect a pool's water balance (Skelly et al. 2005). 
A rich body of literature has documented pool breeding amphibian migration and dispersal distances from breeding pools (Richter et al. 2001; Semlitsch 2002; Faccio 2003; Regosin et al. 2003; Cushman 2006; Baldwin et al. 2006b; Patrick et al. 2006; Rittenhouse and Semlitsch 2007, see review in Semlitsch and Skelly 2008). It is generally accepted that the area within $300 \mathrm{~m}$ of a breeding pool is core foraging and migration habitat for most adult pool breeding species (Rittenhouse and Semlitsch 2007; Harper et al. 2008), but this area can exceed 1,000 m (e.g., Humphries and Sisson 2012). Genetically significant linkages among pools typically occur in neighborhoods of pool based populations within $10 \mathrm{~km}$ of one another (see Smith and Green 2005; Gibbs and Reed 2008). Data on juvenile movement is limited because it is often not possible to conduct radio telemetry studies on animals this size (but see Roznik and Johnson 2009). Alternative methods (e.g., fluorescent powder tracking or pit tagging) only allow for short term assessment of microhabitat needs and movement pattern (Emanetoglu et al. 2013). Dispersing juveniles may travel in excess of $1 \mathrm{~km}$ from natal pools (Patrick et al. 2006; Gamble et al. 2007), if not significantly farther (Smith and Green 2005). Frogs typically travel farther than salamanders, and females generally travel farther than males (Regosin et al. 2003; Rittenhouse and Semlitsch 2007). Although it is not usually feasible for a mitigation project to control habitat quality at these distances, the constraints imposed by this larger landscape perspective should be recognized because landscape context is crucial to the functioning of pools (see Kentula 2000; Zedler 2000; Regosin et al. 2005; Julian 2009; Gardner et al. 2007) and to preserve local genetic diversity (Gibbs and Reed 2008; Richter et al. 2013b). Many researchers have documented that amphibians are particularly sensitive to pool context and quality of the surrounding habitat (Kolozsvary and Swihart 1999; Lehtinen et al. 1999; Guerry and Hunter 2002; Babbitt et al. 2009; Simon et al. 2009).

We know of only one peer reviewed journal article that provides prescriptive measures for the spatial configuration of pools at the landscape scale. Petranka and Holbrook (2006) urged restoration ecologists who are designing creation or restoration projects to consider whether natural pools are patchy (clustered, allowing free flow from pool to pool within a single amphibian population) or distant (suggesting a meta-population 
structure with limited interaction among pools). If pools are patchy, they suggest that creation should provide clusters of pools with varying hydro-periods to support local anti-predator responses (i.e., allowing amphibians to switch to pools with less predation pressure, which can fluctuate annually). However, we note that "landscape" is a term that can be used at many scales and one needs to think about particular species to assess whether pools are "patchy" or "distant." For example, are pools within genetic neighborhoods of dispersing amphibians, and are there significant barriers interrupting typical movement patterns?

Emulating natural patterns of pool distribution and post-breeding habitat may be difficult depending on the extent and spatial pattern of the disturbance that initiated the mitigation effort, availability of suitable terrestrial habitat and suitable pool sites, and access to information on historical patterns of pools or other wetlands. For example, Denton and Richter (2013) and Drayer (2012) compared created and natural wetlands on ridgetops in Kentucky's Daniel Boone National Forest and found that the creation of permanent pools over the last 20 years has likely provided avenues of dispersal and migration for green frogs, bullfrogs, and eastern newts, thereby potentially exposing naturally occurring ridge top amphibian species to direct predation and to diseases such as Batrachochytrium dendrobatidis (amphibian chytrid fungus) and ranavirus (Daszak et al. 2004; Gahl et al. 2009; Greenspan et al. 2012; Richter et al. 2013a). In that landscape, permanent created pools did not support wood frogs and marbled salamanders; those species remained restricted to natural, ephemeral pools.

\section{Summary}

Collectively, the peer reviewed literature cautions against assuming pool creation will successfully create suitable habitat for target vernal pool species. It suggests that the key to effective vernal pool creation is attention to context: what was the historical landscape distribution of wetlands and vernal pools and what is the current distribution? Seen through the lens of past and present wetland status, the sometimes blurred or conflicting messages from the current technical and scientific literature come into focus. For example, in some 
cases, where natural pools have been highly degraded or locally extirpated, creation may be the only option in efforts to support wetland dependent wildlife. This perspective underlies the work of Biebighauser (2003) whose guidance for creating pools was developed in a region with limited wetland resources where providing habitat for any wetland wildlife is likely to be judged desirable (also see Brand and Snodgrass 2009; Simon et al. 2009; Brown et al. 2012). However, such creation efforts carry a high risk of failure for vernal pool species that are sensitive to predators associated with more permanent waters and those that need adjacent forest for postbreeding habitat (e.g., wood frogs) (Boone et al. 2008; Drayer 2012; Denton and Richter 2013; Kross 2014).

Our review of the literature indicates that vernal pool creation is an imperfect science and should be used as a last resort after exhausting more reliable protective methods (Calhoun et al. 2005; Windmiller and Calhoun 2008; Denton and Richter 2013). The practice is perhaps appropriate in landscapes that have been subjected to severe wetland losses, such as former agricultural landscapes where forests have recovered but drained and destroyed wetlands have not. Vernal pool ecosystems are difficult candidates for creation because the community structure is as tied to the surrounding forested ecosystems as to the actual pool depression and because pool function is so tightly tied to hydrology. In addition, ideal breeding site characteristics may vary among pool breeding species regionally (Snodgrass et al. 2000; Petranka et al. 2007) as do post breeding habitat quality tolerances (Windmiller et al. 2008). For these reasons, mitigation efforts must, first and foremost, consider conserving existing pools in a suitable landscape, and, if that is impossible, seek to emulate pools in the region in terms of hydro-geomorphic setting, spatial distribution, and natural amphibian communities.

\section{Recommendations}

Pool specific

- If pool hydro-period is successfully recreated, generally the rest will follow if source populations exist within 
viable colonization distances. However, hydro-period is perhaps the most difficult parameter to reproduce. Therefore, we caution practitioners to carefully consider the effects of substrate composition, compaction, maintenance of canopy, and construction on pool fauna when building vernal pools. If pool hydrology is permanent or even semi-permanent with connections to other waters, fish and amphibian species typically restricted to permanent wetlands may colonize the pool and decimate vernal poolbreeding amphibians by depredating both egg masses and larvae. If the vegetation structure is complex, some ambystomatid species may be able to breed successfully for a while, but evidence suggests that wood frogs will not persist (Vasconcelos and Calhoun 2006; Denton and Richter 2013; Julian et al. 2013; Kross 2014).

- We recommend that practitioners create pools that support appropriate, natural vegetation (Pearl et al. 2005), hydro-geomorphic setting, and soil type and compaction as much as possible. Limiting removal of adjacent trees and root damage during construction will preserve canopy cover, and reducing soil compaction will facilitate colonization by herbaceous plants and trees. Obviously, reestablishment of mature forest, which is often the dominant cover associated with vernal pools in this region, may take many decades. Wood frogs and ambystomatid species will use shrubs and persistent graminoids for egg attachment sites.

- Because littoral zones with a gradual slope are important for life history requirements of some species (e.g., marbled salamanders) and provide more opportunity for establishment of vegetation, thermoregulation of larvae, and refuge from predation, we recommend emulating slopes of local, natural pools.

Landscape and population scale considerations

- We recommend paying attention to local landscape context and desired endpoints of mitigation. Pool breeding amphibians may be organized in meta-populations that function through exchanges among pools following catastrophic events (rescue and colonization processes) and that depend upon relatively long distance dispersal events to maintain genetic integrity (Gibbs and Reed 2008). Alternatively, pool breeding 
amphibians may occur in patchy populations when pools are relatively close $(<500 \mathrm{~m})$ making pools of varying hydro-period in close proximity important for allowing natural exchanges of breeding adults in responses to within pool habitat conditions (e.g., responding to changing predator densities in pools; see Petranka and Holbrook 2006).

- We advise against creating permanent pools. Addition of created pools with permanent hydro-periods, especially at unnaturally high densities, may subsidize local populations of bullfrogs, green frogs, and eastern newts. This can negatively affect nearby pool breeding specialists by increasing predation pressure on eggs and larvae and by increasing the likelihood of disease introductions (Gahl et al. 2009; Brown et al. 2012; Greenspan et al. 2012; Denton and Richter 2013), thus potentially creating population sinks. This possibility argues against the strategy of creating an excess number of vernal pools in the hope that some portion of them will have the correct hydro-period.

- We recommend ample post breeding habitat and pool connections be maintained for long term amphibian population persistence. The $30 \mathrm{~m}$ surrounding pools often serves as critical habitat for newly emerged amphibians and should provide ample canopy cover, leaf litter, and coarse woody material for cover and foraging (Regosin et al. 2003; deMaynadier and Houlahan 2008). However, persistence of populations is favored by at least $300 \mathrm{~m}$ of forested habitat and connections that allow movements among pools and pool clusters.

Measures of success over the monitoring period

- Presence of an amphibian species is a poor indicator of population health; individuals may be transient animals that are no longer able to breed successfully in the pool. Trends in abundance of target species over at least 5 years post creation is a better measure of population robustness, although even abundance may not reflect breeding success in the pool. Ideally, the best measure of success is evidence of breeding and metamorphosis by intended species over five or more years. 
- We recommend a minimum of five years of post-creation monitoring reproductive effort of target species (number of egg masses laid) and recruitment (number of animals successfully metamorphosing and returning to breed). Seemingly functional pools may be ecological traps where individuals breed but where larvae are not able to mature and leave the pool; thus recruitment is a superior metric to egg mass counts. Survivorship to metamorphosis is a better predictor of population health than status of eggs or larvae (Richter et al. 2003; Cushman 2006; Rittenhouse and Semlitsch 2007; Harper et al. 2008).

- Similarly, because it may take a number of years for invasive vegetation to occupy and dominate a pool, we recommend monitoring pool vegetation for at least five years after creation. We do not recommend using species richness as an indicator of pool success (or the contribution of that pool to regional biodiversity). In fact, richness can be similar between constructed and natural pools across the same landscape, while community composition is different, driven by the presence of species not historically breeding in the ecosystem (Drayer 2012; Denton and Richter 2013). Wood frogs and most of the region's ambystomatid salamanders are forest pool specialists, in part because shaded pools are less likely to harbor competitors and predators including green frogs, bullfrogs, northern leopard frogs, pickerel frogs (Lithobates palustris), and eastern newts (Korfel et al. 2009).

- We strongly discourage using occupation by widespread, generalist species such as green frogs and their tadpoles as a criterion for success as such species do not adequately replace pool functions or contribute to landscape scale biodiversity. In contrast, these species are an indicator of failure to replace pool functions, especially for wood frogs.

- We also recommend monitoring from a long term perspective because natural vernal pools tend towards extreme variability, from pool to pool and even within the same pool from year to year. Just as a natural vernal pool may not be productive or "successful" in a given year, a similar allowance should be considered in evaluating created pools. Factors such as weather, ecological context, and the developmental and demographic needs of target species can inform locally appropriate success criteria. Indeed, we hypothesize that having occasional years where pool hydro-period is very short may facilitate amphibian reproductive 
success over the long run by both limiting disease and reducing populations of predatory invertebrates.

Adaptive management

We recommend an adaptive approach (see Salafsky et al. 2001) to management of vernal pools, in which scientists and practitioners collaborate. First and foremost, it should be determined if there is a need for vernal pool creation based on the historical distribution and abundance of vernal pools and other wetlands, the loss and degradation of these resources, and the desired future condition. This discussion should include diverse stakeholders (e.g., landowners, government officials, scientists, practitioners, and others) so that the best management policy for a particular region can be determined (Jansujwicz et al. 2013a, 2013b). Following this, management protocols (i.e., construction techniques) should be developed by key technical stakeholders including scientists, engineers, and managers. Scientists should then monitor the success of pool creation based on multiple indicators, including hydro-period and successful reproduction by focal amphibian species. These results should be used to refine approaches to construction, if necessary. As part of the iterative process, research might be necessary to determine the appropriate construction techniques based on native soils, hydrogeographic characteristics, and other factors affecting hydrology (Brown and Richter 2012; Drayer 2012; Denton and Richter 2013).

Future Research Needs

Even if practitioners consult the papers discussed in this review before embarking on mitigation activities, they offer little technical guidance, especially in terms of assuring ecologically successful outcomes. Below are research needs that became obvious as a result of our review:

- Regional studies are needed to determine appropriate compaction parameters based on ambient soil texture, water source (surface/precipitation versus groundwater), and geomorphology of proposed 
construction sites. The interaction of these parameters should be considered relative to resulting hydroperiods as well as biological outcomes.

- Post-breeding habitat requirements of vernal pool species need to be better defined across their ranges to inform landscape quality and quantity issues such as directing vernal pool creation projects to landscape contexts in which they have the greatest probability of success.

- Soil and substrate structure of vernal pools needs further study so that the implications of using compacted soil to retain water is balanced against other life history needs.

- Longer term studies will reveal the permanence of outcomes observed within typical monitoring periods $(<5$ years) and if successional trajectories in created pools differ from natural pools, which are themselves poorly studied in this regard. Rapidly changing climatic conditions may also necessitate reevaluation of earlier research, as well as present opportunities to design pools to accommodate predicted effects of climate change on wetland-dependent wildlife.

- Reporting outcomes, both positive and negative, is the only means by which the practice of vernal pool creation will progress. Whether in project reports or peer reviewed articles, including sufficient detail about pool design parameters and landscape context is essential to guide future projects as well as research, especially when these characteristics can be correlated with outcomes. 


\section{Acknowledgments}

This is Maine Agriculture and Forestry Experiment Station Publication 3371 


\section{Figures}

\section{Figure 1}

Amphibian species use vernal pools for oviposition and larval rearing according to different schedules throughout the year. Typical species such as wood frogs and spotted salamanders migrate to pools in late winter or early spring, but larval development takes several weeks longer for spotted salamanders than for wood frogs. In contrast, marbled salamanders migrate to pools in late summer and deposit eggs in terrestrial nest sites within the dry basin. Embryos hatch following autumn inundation, and larvae overwinter and metamorphose on a schedule similar to wood frogs. Data are based on movement phenology of adults and metamorphosed amphibians reported by Paton and Crouch (2002) in Rhode Island, U.S.A.; shading gradient between endpoints and black interior reflects 5-95 \% range of cumulative percentiles of number of migrants. Changes in latitude, altitude, and weather will influence end points. For example, Guttman et al. (1991) estimated that wood frog breeding commences a mean of 5.2 days later per additional degree of latitude

\section{Wood frog}

\section{Spotted salamander}

\section{Marbled salamander}

Marbled salamander

\begin{tabular}{|l|l|l|l|l|l|l|l|l|l|l|l|}
\hline $\mathrm{J}$ & $\mathrm{F}$ & $\mathrm{M}$ & $\mathrm{A}$ & $\mathrm{M}$ & $\mathrm{J}$ & $\mathrm{J}$ & $\mathrm{A}$ & $\mathrm{S}$ & $\mathrm{O}$ & $\mathrm{N}$ & $\mathrm{D}$ \\
\hline
\end{tabular}




\section{References}

Babbitt KJ, Baber MJ, Tarr TL (2003) Patterns of larval amphibian distribution along the wetland hydro-period gradient. Can J Zool 81:1539-1552

Babbitt KJ, Baber MJ, Childers DL, Hocking D (2009) Influence of agricultural upland habitat type on larval anuran assemblages in seasonally inundated wetlands. Wetlands 29:294-301

Baldwin RF, deMaynadier PG (2009) Assessing threats to pool breeding amphibian habitat in an urbanizing landscape. Biol Conserv 142: 1628-1638

Baldwin RF, Calhoun AJK, deMaynadier PG (2006a) The significance of hydro-period and stand maturity for pool breeding amphibians in forested landscapes. Can J Zool 84:1604-1615

Baldwin RF, Calhoun AJK, deMaynadier PG (2006b) Conservation planning for amphibian species with complex habitat requirements: a case study using movements and habitat selection of the wood frog Rana sylvatica. J Herpetol 40:443-454

Battaglin WA, Rice KC et al (2009) The occurrence of glyphosate, atrazine, and other pesticides in vernal pools and adjacent streams in Washington, DC, Maryland, lowa, and Wyoming, 2005-2006. Environ Monit Assess 155:281-307

Biebighauser TR (2003) A guide to creating vernal ponds. USDA Forest Service, South Morehead

Biebighauser TR (2011) Wetland restoration and construction: a technical guide. Upper Susquehanna Coalition, Owego

Black C, Zedler PH (1996) An overview of 15 years of vernal pool restoration and construction activities in San Diego County, California. In: Witham CW, Bauder ET, Belk D, Ferren WR Jr, Ornduff R (eds) Ecology, conservation, and management of vernal pool ecosystems - proceedings from a 1996 conference. California Native Plant Society, Sacramento, pp 195-205

Boone MD, Semlitsch RD, Mosby C (2008) Suitability of golf course ponds for amphibian metamorphosis when bullfrogs are removed. Conserv Biol 22:172-179

Brady SP (2012) Road to evolution? Local adaptation to road adjacency in an amphibian (Ambystoma maculatum). Scientific Reports 2 Brainwood M, Burgin S (2009) Hotspots of biodiversity or homogeneous landscapes? Farm dams as biodiversity reserves in Australia. Biodivers Conserv 18:3043-3052

Brand AB, Snodgrass JW (2009) Value of artificial habitats for amphibian reproduction in altered landscapes. Conserv Biol 24:295-301

Brooks RP, Gebo NA (2013) Wetlands mitigation and restoration. In: Brooks RP, Wardrop DH (eds) Mid Atlantic freshwater wetlands: advances in wetlands science, management, policy, and practice. Springer Science+Business Media, NY, pp 421-440

Brooks RT, Stone J, Lyons P (1998) An inventory of seasonal forest ponds on the Quabbin reservoir watershed, Massachusetts. Northeast Nat 5:219-230

Brown DR, Richter SC (2012) Meeting the challenges to preserving Kentucky's biodiversity. Sustainability 25:22-33

Brown DJ, Street GM, Nairn RW, Forstner MRJ (2012) A place to call home: amphibian use of created and restored wetlands. Article 989872: International Journal of Ecology

Calhoun AJK, deMaynadier P (2002) Forestry habitat management guidelines for vernal pool wildlife in Maine. Wildlife 
Conservation Society Technical Paper \#6 Rye, NY

Calhoun AJK, deMaynadier P (2008) Science and conservation of vernal pools in northeastern North America. CRC Press, Boca Raton, Florida Colburn EA (2004) Vernal pools: natural history and conservation. McDonald and Woodward Publishing Company, Blacksburg, VA

Calhoun AJK, Miller NA, Klemens MW (2005) Conserving poolbreeding amphibians in human dominated landscapes through local implementation of best development practices. Wetl Ecol Manag 13: 291-304

Colburn E, Weeks SC, Reed SK (2008) Diversity and ecology of vernal pool invertebrates. In: Calhoun AJK, deMaynadier PG (eds) Science and conservation of vernal pools in Sortheastern North America. CRC Press, Boca Raton, pp 107-124

Cole CA, Brooks RP (2000) Patterns of wetland hydrology in the ridge and valley province, Pennsylvania, USA. Wetlands 20: 438-447

Compton BW, McGarigal K, Cushman SA, Gamble LR (2007) A resistant kernel model of connectivity for amphibians that breed in vernal pools. Conserv Biol 21:788-799

Council NR (1992) Restoration of aquatic ecosystems. National Academy Press, Washington

Council NR (2001) Compensating for wetland losses under the clean water Act. National Academy Press, Washington

Croshaw DA, Scott DE (2006) Marbled salamanders (Ambystoma opacum) choose low elevation nest sites when cover availability is controlled. Amphibia Reptilia 27:359-364

Cushman SA (2006) Effects of habitat loss and fragmentation on amphibians: a review and prospectus. Biol Conserv 128: 231-240

Cutko A, Rawinski RJ (2008) Flora of Northeastern vernal pools. In: Calhoun AJK, deMaynadier PE (eds) Science and conservation of vernal pools in Northeastern North America. CRC Press, Boca Raton, pp 71-104

da Silva FR, Gibbs JP, Rossa Feres DD (2011) Breeding habitat and landscape correlates of frog diversity and abundance in a tropical agricultural landscape. Wetlands 31:1079-1087

Dahl TE (2011) Status and trends of wetland in the conterminous United State 2004 to 2009. U.S. Department of the Interior, Fish and Wildlife Service, Washington

Daszak P, Cunningham AA, Loncore JE, Brown C, Porter D (2004) Experimental evidence that the bullfrog (Rana catesbeiana) is a potential carrier of chytridiomycosis, and emerging fungal disease of amphibians. Herpetol J 14:201-207

deMaynadier PG, Hunter ML Jr (1995) The relationship between forest management and amphibian ecology: a review of the North American literature. Environ Rev 3:230-261

deMaynadier PG, Hunter ML Jr (1999) Forest canopy closure and juvenile emigration by pool breeding amphibians in Maine. J Wildl Manag 63:441-450

Denton RD, Richter SC (2013) Amphibian communities in natural and constructed ridge top wetlands with implications for wetland construction. J Wildl Manag 77:886-889

Dimauro D, Hunter ML Jr (2002) Reproduction of amphibians in natural and anthropogenic temporary pools in managed forests. For Sci 48: 397-406

Drayer AN (2012) Efficacy of constructed wetlands of various depths for natural amphibian community conservation. Thesis, Eastern Kentucky University, KY

Emanetoglu NW, Aumann HM, Kus EM, Cline BB (2013) A low cost harmonic radar for tracking very small tagged 
amphibians. IEEE (Institute of Electrical and Electronics Engineers) Transactions on Instrumentation and Measurement

Faccio SD (2003) Postbreeding emigration and habitat use by Jefferson and spotted salamanders in Vermont. J Herpetol 37:479-489

Gahl MK, Calhoun AJK, Graves R (2009) Facultative use of seasonal pools by American bullfrogs (Rana catesbeiana). Wetlands 29: 697-703

Gahl MK, Longcore JE, Houlahan JE (2012) Varying responses of northeastern North American amphibians to the chytrid pathogen Batrachochytrium dendrobatidis. Conserv Biol 26: 135-141Gamble DL, Mitsch WJ (2009) Hydro-periods of created and natural vernal pools in central Ohio: a comparison of depth and duration of inundation. Wetl Ecol Manag 17:385-395

Gamble LR, McGarigal K, Compton BW (2007) Fidelity and dispersal in the pond breeding amphibian, Ambystoma opacum: implications for spatio temporal population dynamics and conservation. Biol Conserv 139:247-257

Gardner TA, Barlow J, Peres CA (2007) Paradox, presumption, and pitfalls in conservation biology: the importance of habitat change for amphibians and reptiles. Biol Conserv 138:166-179

Gebo NA, Brooks RP (2012) Hydro-geomorphic (HGM) assessments of mitigation sites compared to natural reference wetlands in Pennsylvania. Wetlands 32:321-331

Gibbs JP (1998) Distribution of woodland amphibians along a forest fragmentation gradient. Landsc Ecol 13:263-268

Gibbs JP, Reed JM (2008) Population and genetic linkages of vernal pool associated amphibians. In: Calhoun AJK, deMaynadier PG (eds) Science and conservation of vernal pools in northeastern North America. CRC Press, Boca Raton, pp 149-167

Good CD (2006) Constructed ponds as mitigated habitat for the wood frog (Rana sy/vatica LeConte) and the spotted salamander (Ambystoma maculatum Shaw) in West Virginia. Thesis, Marshall University, WV

Gray MJ, Miller DL, Hoverman JT (2009) Ecology and pathology of amphibian ranaviruses. Dis Aquat Org 87:243-266

Greenspan SE, Calhoun AJK, Loncore JE, Levy MG (2012) Transmissions of Batrachochytrium dendrobatidis to wood frogs (Lithobates sylvaticus) via a Bullfrog (L. catesbeianus) vector. J Wildl Dis 48:575-582

Greenwald KR, Gibbs HL, Waite TA (2009) Efficacy of land cover models in predicting isolation of marbled salamander populations in a fragmented landscape. Conserv Biol 23:1232-1241

Guerry AD, Hunter ML Jr (2002) Amphibian distributions in a landscape of forests and agriculture: an examination of landscape composition. Conserv Biol 16:745-754

Guttman SI, Bramble JE, Sexton OJ (1991) Observations on the breeding immigration of wood frogs Rana sylvatica reintroduced in eastcentral Missouri. Am Midl Nat 125:269-274

Harper EB, Rittenhouse TAG, Semlitsch RD (2008) Demographic consequences of terrestrial habitat loss for pool breeding amphibians: predicting extinction risks associated with inadequate size of buffer zones. Conserv Biol 22:1205-1215

Hoeltje SM, Cole CA (2007) Losing function through wetland mitigation in central Pennsylvania, USA. Environ Manag 39:385-402

Homan RN, Windmiller BS, Reed JM (2004) Critical thresholds associated with habitat loss for two vernal pool breeding amphibians. Ecol Appl 14:1547-1553 
Humphries WJ, Sisson MA (2012) Long distance migrations, landscape use, and vulnerability to prescribed fire of the gopher frog (Lithobates capito). J Herpetol 46:665-670

Jansujwicz JS, Calhoun AJK, Leahy JE, Lilieholm RJ (2013a) Using mixed methods to develop a frame based private landowner typology. Soc Nat Resour Int J. doi:10.1080/08941920.2012.729294

Jansujwicz JS, Calhoun AJK, Lilieholm R (2013b) The Maine vernal pool mapping and assessment program: engaging municipal officials and private landowners in community based citizen science. Environ Manag. doi:10.1007/s00267 0130168

Julian JT (2009) Evaluating amphibian occurrence models and the importance of small, isolated wetlands in the Delaware Water Gap National Recreational Area. Dissertation, Pennsylvania State University, PA

Julian JT, Rocco G, Turner MM, Brooks RP (2013) Assessing wetlandriparian amphibian and reptile communities of the Mid Atlantic region. In: Brooks RP, Wardrop DH (eds) Mid Atlantic freshwater wetlands: advances in wetlands science, management, policy, and practice. Springer Science and Business Media, NY, pp 313-337

Karraker NE, Gibbs JP, Vonesh JR (2008) Impacts of road deicing salt on the demography of vernal pool breeding amphibians. Ecol Appl 18: 724-734

Kentula ME (2000) Perspectives on setting success criteria for wetland restoration. Ecol Eng 15:199-209

Kentula ME, Brooks RP, Gwin SE, Holland CC, Sherman AD, Sifneos JC (1992) An approach to improving decisionmaking in wetland restoration and creation. Island Press, Washington

King SK (2012) Four toed salamander (Hemidactylium scutatum) nest site characteristics in natural and constructed wetlands in eastern Kentucky. Thesis, Eastern Kentucky University

Kolozsvary MB, Swihart RK (1999) Habitat fragmentation and the distribution of amphibians: patch and landscape correlates in farmland. Can J Zool 77:1288-1299

Korfel CA, Mitsch WJ, Hetherington TE, Mack JJ (2009) Hydrology, physiochemistry, and amphibians in natural and created vernal pool wetlands. Restor Ecol 18:843-854

Kross, CS (2014) Interactions between eastern newts and wood frogs in an anthropogenically altered wetland system in eastern Kentucky. Thesis, Eastern Kentucky University, KY

Kusler JS, Kentula ME (1990) Wetland creation and restoration: the status of the science. Island, Washington

Lehtinen RM, Galatowitsch SM, Tester JR (1999) Consequences of habitat loss and fragmentation for wetland amphibian assemblages. Wetlands 19:1-12

Leibowitz SG (2003) Isolated wetlands and their functions: an ecological perspective. Wetlands 23:517-531

Lichko LE, Calhoun AJK (2003) An evaluation of vernal pool creation projects in New England: project documentation from 1991-2000. Environ Manag 32:141-151

Magnusson AK, Williams DD (2006) The roles of natural temporal and spatial variation versus biotic influences in shaping the physicochemical environment of intermittent ponds: a case study. Arch Hydrobiologia 165:537-556

Mahaney WS, Klemens MW (2008) Vernal pool conservation policy: the federal, state, and local context. In: Calhoun AJK, deMaynadier PG (eds) Science and conservation of vernal pools in northeastern North America. CRS Press, Boca Raton, pp 19-212

McDonough Haughley C, Paton PWC (2007) Spotted salamander dispersal across a forested landscape fragmented by a golf 
course. J Wildl Manag 71:1163-1169

Moreno Mateos D, Power ME, Comin FA, Yockteng R (2012) Structural and functional loss in restored wetland ecosystems. PLoS Biol 10: e1001247

Newman RA (1998) Ecological constraints on amphibian metamorphosis: interactions of temperature and larval density with responses to changing food level. Oecologia 115:9-16

Palik B, Batzer DP, Kern C (2006) Upland forest linkages to seasonal wetlands: litter flux, processing, and food quality. Ecosystems 9: 142-151

Paton PWC, Crouch WB III (2002) Using the phenology of pondbreeding amphibians to develop conservation strategies. Conserv Biol 16:194-204

Patrick DA, Hunter ML Jr, Calhoun AJK (2006) Effects of experimental forestry treatments on a Maine amphibian community. For Ecol Manag 234:323-332

Pearl CA, Adams MJ, Leuthold N, Bury RB (2005) Amphibian occurrence and aquatic invaders in a changing landscape: implications for wetland mitigation in Willamette Valley, Oregon, USA. Wetlands 25:76-88

Pennsylvania Natural Heritage Program (2013) http://www. naturalheritage.state.pa.us/factsheets/15236.pdf accessed 6 June 2013

Peterman WE, Feist SM, Semlitsch RD, Eggert LS (2013) Conservation and management of peripheral populations: spatial and temporal influences on the genetic structure of wood frog (Rana sylvatica) populations. Biol Conserv 158:351358

Petranka JW, Holbrook CT (2006) Wetland restoration for amphibians: should local sites be designed to support metapopulations or patchy populations? Restor Ecol 14:404-411

Petranka JW, Murray SW, Kennedy CA (2003) Response of amphibians to restoration of a southern Appalachian wetland: perturbations confound post restoration assessment. Wetlands 23:278-290

Petranka JW, Harp EM, Holbrook CT, Hamel JA (2007) Long term persistence of amphibian populations in a restored wetland complex. Biol Conserv 138:371-380

Porej D, Hetherington TE (2005) Designing wetlands for amphibians: the importance of predatory fish and shallow littoral zones in structuring amphibian communities. Wetl Ecol Manag 13:445-455

Porej DP, Micacchion M, Hetherington TE (2004) Core terrestrial habitat for conservation of local populations of salamanders and wood frogs in agricultural landscapes. Biol Conserv 120:399-409

Raffel TR, Michel PJ, Sites EW, Rohr JR (2010) What drives chytrid infections in newt populations? Associations with substrate, temperature, and shade. EcoHealth 7:526-536

Regosin JV, Windmiller BS, Reed JM (2003) Terrestrial habitat use and winter densities of the wood frog (Rana sylvatica). J Herpetol 37: 390-394

Regosin JV, Windmiller BS, Homan RN, Reed JM (2005) Variation in terrestrial habitat use by four pool breeding amphibian species. J Wildl Manag 69:1481-1493

Rice KJ, Emery NC (2003) Managing microevolution: restoration in the face of global change. Front Ecol Environ 1:469-478

Richter SC, Young JE, Seigel RA, Johnson GN (2001) Post breeding movements of the dark gopher frog, Rana sevosa goin and netting: implications for conservation and management. J Herpetol 35:316-321 
Richter SC, Young JE, Johnson GN, Seigel RA (2003) Stochastic variation in reproductive success of a rare frog, Rana sevosa: implications for conservation and for monitoring amphibian populations. Biol Conserv 111:171-177

Richter SC, Drayer AN, Strong JR, Kross CS, Miller DL, Gray MJ (2013a) High prevalence of ranavirus infection in permanent constructed wetlands in eastern Kentucky, USA. Herpetol Rev 44:464-466

Richter SC, Price SJ, Kross CS, Alexander JR, Dorcas ME (2013b) Upland habitat quality and historic landscape composition Influence genetic variation of a pond breeding salamander. Diversity 5:724-733

Rittenhouse TAG, Semlitsch RD (2007) Postbreeding habitat use of wood frogs in a Missouri Oak Hickory forest. J Herpetol 41: 645-653

Roznik EA, Johnson SA (2009) Canopy closure and emigration by juvenile gopher frogs. J Wildl Manag 73:260-268

Ruhi A, Sebastian OS, Feo C, Franch M, Gascon S, Richter Boix A, Bois D, Llorente G (2012) Man made Mediterranean temporary ponds as a tool for amphibian conservation. Annales de Limnologie Int J Limnol 48:81-93

Sacerdote AB, King RB (2009) Dissolved oxygen requirements for hatching success of two ambystomatid salamanders in restored ephemeral ponds. Wetlands 29:1202-1213

Salafsky N, Marogoluis R, Redford K (2001) Adaptive management: a tool for conservation practitioners. Washington, DC Schiesari L (2006) Pond canopy cover: a resource gradient for anuran larvae. Freshw Biol 51:412-423

Seigel RA, Dinsmore A, Richter SC (2006) Artificial respiration for ponds: experimental use of well water to increase hydroperiod as a management option for temporary pond breeding amphibians. Wildl Soc Bull 34:1022-1027

Semlitsch RD (1998) Biological delineation of terrestrial buffer zones for salamanders. Conserv Biol 12:1113-1119 Semlitsch RD (2002) Critical elements for biologically based recovery plans for aquatic breeding amphibians. Conserv Biol 16: 619-629

Semlitsch RD (2008) Moving wetland mitigation towards conservation banking. Nati Wetl Newsl 30:16

Semlitsch RD, Skelly DK (2008) Ecology and conservation of poolbreeding amphibians. In: Calhoun AJK, deMaynadier PG (eds) Science and conservation of vernal pools in Northeastern North America. CRC Press, Boca Raton, pp 127-148

Semlitsch RD, Todd BD, Blomquist SM et al (2008) Effects of timber harvest on amphibian populations: understanding mechanisms from forest experiments. Bioscience 59:853-862

Shulse CD, Semlitsch RD, Trauth KM, Gardner JE (2012) Testing wetland features to increase amphibian reproductive success and species richness for mitigation and restoration. Ecol Appl 22: 1675-1688

Simon JA, Snodgrass JW, Casey RE, Sparling DW (2009) Spatial correlates of amphibian use of constructed wetlands in an urban landscape. Landsc Ecol 24:361-373

Skelly DK, Werner EE, Cortwright SA (1999) Long term distributional dynamics of a Michigan amphibian assemblage. Ecology 80:2326-2337

Skelly DK, Freidenburg LK, Kiesecker JM (2002) Forest canopy and the performance of larval amphibians. Ecology 83:983992

Skelly DK, Halverson AM, Freidenburg LK, Urban MC (2005) Canopy closure and amphibian diversity in forested wetlands. Wetl Ecol Manag 13:261-268

Skidds DE, Golet FC, Paton PWC, Mitchell JC (2007) Habitat correlates of reproductive effort in wood frogs and spotted salamanders in an urbanizing watershed. J Herpetol 41:439-450 
Smith AM, Green DM (2005) Dispersal and the metapopulation paradigm in amphibian ecology and conservation: are all amphibian populations metapopulations? Ecography 28:110-128

Snodgrass JW, Domoroski MJ, Bryan AL Jr, Burger J (2000) Relationships among isolated wetland size, hydro-period, and amphibian species richness: implications for wetland regulations. Conserv Biol 14:414-419

Stauffer AL, Brooks RP (1997) Plant and soil responses to salvaged marsh surface and organic matter amendments at a created wetland in central Pennsylvania. Wetlands 17:90-105

Timm BC, McGarigal K, Gamble LR (2007) Emigration timing of juvenile pond breeding amphibians in western Massachusetts. J Herpetol 41:243-250

Tiner RW, Veneman PLM (1989) Hydric soils of New England. University of Massachusetts Cooperative Extension Communication Center, Amherst

U.S. Environmental Protection Agency (2008) Compensatory mitigation for losses of aquatic resources. Fed Regist 73:19594-19705

Vasconcelos D, Calhoun AJK (2004) Movement patterns of adult and juvenile wood frogs (Rana sylvatica) and spotted salamanders (Ambystoma maculatum) in three restored vernal pools. J Herpetol 38:551-561

Vasconcelos D, Calhoun AJK (2006) Monitoring created seasonal pools for functional success: a six year case study of amphibian responses, Sears Island, Maine, USA. Wetlands 26:992-1003

Wellborn GA, Skelly DK, Werner EE (1996) Mechanisms creating community structure across a freshwater habitat gradient. Ann Rev Ecol Syst 27:337-363

Whigham DF, Jordan TE (2003) Isolated wetlands and water quality.

Wetlands 23:541-549

Whittecar R, Daniels WL (1999) Use of hydro-geomorphic concepts to design created wetlands in southeastern Virginia. Geomorphology 31:355-371

Williams P, Whitfield M, Biggs J (2008) How can we make new ponds biodiverse? A case study monitored over 7 years. Hydrobiologia 597:137-148

Windmiller B, Calhoun AJK (2008) Conserving vernal pool wildlife in urbanizing landscapes. In: Calhoun AJK, deMaynadier PG (eds) Science and conservation of vernal pools in northeastern North America. CRC Press, Boca Raton, pp 233-251

Windmiller BS, Homan RN, Regosin JV, Willitts LA, Wells DL, Reed JM (2008) Two case studies of declines in vernal pool breeding amphibian populations following loss of adjacent upland forest habitat. Urban Herpetology. Herpetological Conservation, Volume 3, Society for the Study of Amphibians and Reptiles, Salt Lake City, Utah Zedler JB (2000) Progress in wetland restoration ecology. Trends Ecol Evol 15:402-407 